Tomasz Gałuszka OP

DOMINIKAŃSKI INSTYTUT HistoRYCZnY

Uniwersytet Papieski Jana PawŁa II w Krakowie

\title{
Krakowscy pobożni laicy czy begardzcy heretycy? Z badań nad czternastowiecznym Tractatus contra beghardos Henryka Harrera
}

\section{Wstęp}

Tractatus contra beghardos ${ }^{1}$ autorstwa czeskiego dominikanina Henryka Harrera jest dziełem o wyjątkowej wartości zarówno dla historyków średniowiecznych ruchów heterodoksyjnych, jak i dla badaczy zajmujących się dziejami teologii i prawa w czternastym stuleciu. Traktat ten powstał na zlecenie krakowskich dominikanów w latach 1328-1334². Zaangażowanie obcego eksperta w osobie Henryka Harrera z praskiego konwentu św. Klemensa wynikało najprawdopodobniej z licznych kontrowersji, jakie pojawiły się wśród krakowskich duchownych odnośnie do oceny działalności pewnej grupy osób, których sposób życia i praktyki religijne odróżniały się od zachowań pozostałych wiernych w tutejszej diecezji³. Czeski dominikanin był doskonale przygotowany do realizacji powie-

${ }^{1}$ Jedyny znany rękopis (XIV/XV w.) Tractatus contra beghardos (dalej: $\mathrm{Cb}$ ) przechowywany jest w Bibliotece Uniwersyteckiej we Wrocławiu, sygn. I F 292, k. 16or ${ }^{\mathrm{a}}-166 \mathrm{v}^{\mathrm{b}}$. Obecnie przygotowuję edycję tekstu. W niniejszym studium wszystkie cytaty z Contra beghardos zostały przytoczone $\mathrm{z}$ zachowaniem oryginalnej ortografii; interpunkcja oraz inne interwencje (uzupełnienia, korekta ewidentnych błędów itp.) pochodzą od autora.

${ }^{2}$ Zob. T. Gałuszka, Harrer (Havrer) Henryk. W: Encyklopedia filozofii polskiej. T. 1. Pod red. A. Maryniarczyka SDB. Lublin 2011, s. 475-476 (tam pełna bibliografia). Dyskusję oraz wyniki badań nad autorstwem i datacją Tractatus contra beghardos przedstawiłem w: Źródło na nowo odkryte. Henryka Harrera „Tractatus contra beghardos”, [w druku].

${ }^{3} \mathrm{Nt}$. genezy powstania Tractatus contra beghardos zob. T. Gałuszka, Kryzys w diecezji krakowskiej w 1. połowie XIV wieku? Z badań nad „Tractatus contra beghardos” Henryka Harrera. 
rzonego mu zadania. O jego wysokich kompetencjach i rzetelności świadczy nie tylko biegłość w źródłach prawniczych, znajomość spuścizny św. Tomasza z Akwinu i umiejętność jej adaptacji w całość wywodu, ale sposób prezentacji samych begardów. Harrer starał się zachować pewien obiektywizm i - z zaskakującą tolerancją - pozwolił oskarżonym na wyczerpujące wyjaśnienie swoich poglądów. Ponadto, zastanawiający jest brak w Tractatus contra beghardos typowych i często spotykanych elementów dyskursu antyheretyckiego, co rodzi uzasadnione przypuszczenie, że Harrer nie mówił o begardach in generale - anonimowych czy też „Wzorcowych”, ale skonstruował swój traktat wokół konkretnych zagadnień, które przekazali mu krakowscy świadkowie. W świetle tej wstępnej hipotezy dzieło Harrera byłoby jednym z nielicznych źródeł na temat ruchów religijnych w czternastowiecznej diecezji krakowskiej.

Zanim jednak przejdę do odpowiedzi na pytanie o głównych bohaterów Contra beghardos, trzeba w pierwszej kolejności wyjaśnić kilka poważnych nieporozumień związanych z takimi terminami, jak „begard” i „begardyzm”.

\section{I}

Jean-Claud Schmitt, jeden z najlepszych znawców zagadnienia begardyzmu średniowiecznego, stwierdził wprost: „les bégards navaient jamais formé une

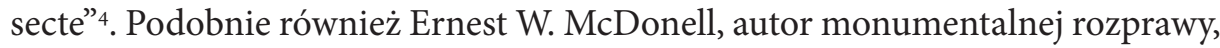
uznawanej za najważniejszy głos w dyskusji nad średniowiecznymi begardami, w ogóle nie wspomina o herezji begardzkiej5. Ponadto, informacji o jej istnieniu nie odnajdziemy także w Heresy in the Later Middle Ages Gordona Leffa ${ }^{6}$ oraz w nowszej literaturze przedmiotu Jak zatem pogodzić fakt nieobecności

W: „Ecclesia semper reformanda”. Kryzysy i reformy średniowiecznego Kościoła. Pod red. G. Rysia, T. Gałuszki, T. Graffa [w druku].

${ }^{4}$ J.-C. Schmitt, Mort d’une hérésie. L’Église et les clercs face aux béguines et aux béghards du Rhin supérieur du XIVe au XVe siècle. W: Civilisations et sociétés. T. 56. Paris 1978, s. 66. Zob. także recenzję książki G. Alain, „Bibliothéque de l'école des chartre” Vol. 137: 1979, s. 331-334.

${ }^{5}$ E. W. McDonell, The Beguines and Beghards in Medieval Culture. With Special Emphasis on the Belgian Scene. New York 1969.

${ }^{6}$ G. Leff, Heresy in the Later Middle Ages. Manchaster 1967.

7 Najnowsza zagraniczna bibliografia nt. begardów zob. przede wszystkim: M. D. Bailey, Battling Demons. Witchcraft, Heresy, and Reform in the Late Middle Ages. Pennsylvania 2002; 
w średniowieczu herezji begardów z licznymi traktatami i opisami, które noszą niepozostawiające żadnych wątpliwości tytuły contra beghardos czy też de erroribus beghardorum? A w kontekście omawianego traktatu Henryka Harrera moglibyśmy jeszcze dodać kolejne pytanie: $\mathrm{W}$ takim razie, do kogo zwracał się czeski dominikanin, gdy wielokrotnie wołał: „Tu vilissime heretice begarde!”? By rozwiązać tę trudność, należy w pierwszej kolejności raz jeszcze pokrótce przeanalizować główne cechy ruchu begardów.

Najstarszą wzmiankę na temat begardów odnajdujemy w dokumencie z 22 grudnia 1252 roku, wystawionym przez hrabinę Małgorzatę, poświadczającym zwolnienie wspólnoty begardów z Brugii z obciążeń podatkowych ${ }^{8}$. Informacje na temat tego ruchu znajdują się również w źródłach kolońskich z 1258 roku' ${ }^{9}$ Dzięki skrupulatnym ustaleniom wspomnianych wyżej E. McDonnella i J.-C. Schmitta wiemy, że rekrutowali się spośród ludzi świeckich, głównie $\mathrm{z}$ warstwy rzemieślniczej i środowisk miejskich. Nigdzie nie ma wzmianek o obecności wśród begardów osób duchownych. Większość z nich pracowała jako robotnicy w przędzalnictwie, które było głównym przemysłem Flandrii i Brabancji. Ponieważ begardzi pomimo przystąpienia do wspólnoty nadal pozostawali osobami świeckimi, stąd też w naturalny sposób utrzymywali ścisłe związki przede wszystkim z władzami miejskimi, które udzielały im protekcji oraz wsparcia finansowego. Jak zauważył E. McDonnell, ,the secular clergy did not at first exercise direct control over the these semireligious communities" ${ }^{\prime \prime}$. Duchowieństwo, głównie świeckie, nie mieszało się w sprawy fundacji begardzkich. Nie zachował się żaden dokument fundacyjny wydany przez biskupa. Nie oznacza to, że biskupi nie interesowali się tym ruchem religijnym. W latach osiemdziesiątych XIII wieku była tylko jedna godna uwagi interwencja biskupa Cambrai Wilhelma z Hainaut ${ }^{11}$. Na prośbę begardów z Malines, skierował on w 1286 roku list do miejscowego kleru, w którym oświadczył, że ci, którzy opuścili wspólnotę lub zostali z niej wydaleni, tracą jakiekolwiek prawa do dóbr związanych z konwentem begardzkim. Ponadto zabronione im było noszenie stroju begardów z Malines. Mistrzowie begardzcy utrzymywali również stałe

C. Kneupper, Reconsidering Fourteenth-Century Heresy Trial in Metz. Beguins and Other. „Franciscana" (Spoleto) R. 8: 2006, s. 187-225.

8 Zob. E. W. McDonell, The Beguines and Beghards..., s. 252-253.

9 Zob. tamże, s. 253.

10 Tamże, s. 257.

${ }^{11}$ Zob. J. Vannérus, Documents concernant les Bogards de Malines (1284-1558). „Bulletin de la Commission royale d'histoire" T. 80: 1911, s. 237-238. 
kontakty z hierarchią kościelną, czego najlepszym świadectwem są liczne przywileje i bulle protekcyjne, udzielone im przez trzynasto- i czternastowiecznych papieży, m.in. Klemensa V, Jana XXII i Urbana V.

Begardzi wybierali stan pośredni pomiędzy życiem zwykłego chrześcijanina a klasycznym życiem klasztornym. Ich intencją nie było odseparowanie się od świata, aby w całości poświęcić się Bogu w zakonie. Nigdzie jednak nie spotykamy u nich formalnego odrzucenia zwyczajowych form życia zakonnego ani też jego otwartej krytyki. Przyswoili sobie nawet niektóre elementy liturgii klasztornej, liczniejsze dni postu, częstsze przyjmowanie sakramentów oraz niektóre przepisy życia we wspólnocie. Generalnie prowadzili życie wspólne w domach lub tzw. konwentach, które rządziły się własną regułą czy raczej regulaminem. Praktyka ubóstwa w poszczególnych domach była zróżnicowana: w jednych członkowie nie zrzekali się własności i mogli czerpać stałe dochody $\mathrm{z}$ różnych źródeł (czynsze, legaty itp.); z kolei w innych konwentach członkowie zrzekali się całej własności na rzecz wspólnoty. Z XIII wieku zachował się jedynie jeden taki regulamin konwentu z Brugii, zredagowany w 1291 roku. Nosi on tytuł Die regle der goeder kinder die men heet Beggarde (Regulamin dobrych dziatek zwanych begardami) ${ }^{12}$. Dla XIV wieku natomiast posiadamy regułę domu w Middelburgu, datowaną na rok $1331^{13}$. W tym ostatnim tekście, współczesnym interesującemu nas traktatowi Henryka Harrera, dowiadujemy się np., że musieli oni zachować czystość, spowiadać się i przyjmować komunię co najmniej siedem razy w roku; członkowie nie mogli opuszczać domów po zmroku; modlili się przed pracą, a na dźwięk dzwonu wszyscy gromadzili się w ściśle określonym miejscu (kaplica, sala, refektarz itp.) w celu wykonania pracy wspólnotowej; w przypadku śmierci członka wspólnoty begardzi odmawiali albo psalmy, albo 700 razy modlitwę Pater noster i Ave Maria lub też 150 razy Psalm Miserere mei Deus.

Jednak wspomniany regulamin z 1331 roku nie może nam przysłonić faktu, że pierwsza połowa XIV wieku to dla begardów czas niespokojny, by nie powiedzieć rewolucyjny. Wówczas rozpoczęła się reorganizacja tego ruchu i de facto powolne jego zanikanie. Niewątpliwie momentem przełomowym był listopad 1311 roku, gdy papież Klemens V zatwierdził dekret soborowy Ad nostrum qui desideranter, potępiający „sektę niegodziwych mężczyzn, którzy w języku po-

${ }_{12}$ Zob. L. Gilliodts-Van Severen, Inventaire diplomatique des archives de l'ancienne école Bogarde à Brugest. T. 2. Brugge 1900, s. 26-30, $\mathrm{nr} 17$.

${ }^{13}$ Zob. E. W. McDonell, The Beguines and Beghards..., s. 261-262. 
tocznym nazywani są begardami oraz niewiernych niewiast, zwanych beginkami”"14. Papież wymienił osiem błędów, dotyczących generalnie jednego proble$\mathrm{mu}$ - status perfectionis. Begardzi mieliby zatem utrzymywać, że człowiek może osiągnąć taki poziom życia duchowego, który uczyniłby go bezgrzesznym, zwalniał z jakichkolwiek form ascezy i praktyk religijnych (postów, modlitwy) oraz posłuszeństwa jakimkolwiek autorytetom, a nawet wymogów życia moralnego. W końcu, potępieni begardzi - według dokumentów soborowych - w swej „przewrotnej doskonałości” mieli również lekceważyć sakrament Eucharystii. Zarzuty te, jak łatwo zauważyć, mocno kontrastują z przedstawionym wcześniej opisem modus vivendi begardów. W rzeczy samej, błędy nie były w żaden sposób ideologią begardzką, lecz najbardziej skrajnej grupy heterodoksyjnej w średniowiecznej Europie - herezji wolnego ducha. Jak wynika z ustaleń Roberta Lernera ${ }^{15}$, herezja ta była w dużej mierze intelektualnym wytworem duchowieństwa niemieckiego. U jej podłoża miało znajdować się przekonanie, że człowiek jest w stanie sam i bez pomocy Kościoła zjednoczyć się z Bogiem i osiągnąć stan doskonałości. Po oficjalnym ogłoszeniu w 1317 roku przez papieża Jana XXII dekretu Ad nostrum rozpoczął się nowy i trudny etap w historii begardów. Należy jednak podkreślić, że cierpieli oni nie tyle z powodu prześladowań i procesów inkwizycyjnych, co głównie z racji podważenia dobrego imienia. Musieli oni również na nowo wypracować podstawy prawne uzasadniające i regulujące ich egzystencję. Najlepszym, a częstokroć jedynym rozwiązaniem była rezygnacja z własnej reguły i przyjęcie zasad życia Trzeciego Zakonu św. Franciszka lub św. Dominika ${ }^{16}$. Warto jednak zaznaczyć, że takie decyzje begardzi podejmowali świadomie i bez przymusu, choć czynniki zewnętrzne mogły wywierać pewien wpływ. Generalnie bowiem łącząc się z wielkimi zakonami mendykanckimi, zapewniali sobie solidny status prawny, co mogło im wyjść tylko na korzyść. Odtąd mogli bowiem upominać się o przywileje przynależne trzecim zakonom i - co więcej - cieszyć się protekcją władz zakonnych.

${ }^{14}$ Dokumenty soborów powszechnych. Opr. A. Baron, H. Pietras. T. 2. Kraków 2003, s. 592-595.

${ }_{15}$ Zob. R. Lerner, The Heresy of the Free Spirit in the Later Middle Ages. Berkeley 1972, s. 78-84. $\mathrm{Na}$ temat herezji wolnego ducha zob. J. Turpinda, Herezja Wolnego Ducha na ziemiach polskich i w Prusach. W: Gdańskie Studia z Dziejów Średniowiecza. Nr 3: Władcy, mnisi, rycerze. Pod red. B. Śliwińskiego. Gdańsk 1996, s. 341-362; P. Kras, Ad abolendam diversarum haeresium pravitatem. System inkwizycyjny w średniowiecznej Europie. Lublin 2006, s. 232-236.

${ }^{16}$ Zob. M. Haverals, Trzeci Zakon świętego Franciszka i begardyzm w południowych Niderlandach (XII-XIV wiek). W: Franciszkanie w Polsce średniowiecznej. Pod red. J. Kłoczowskiego. T. 1. Kraków 1985, s. 137-157. 
Historycy od wielu lat próbują odnaleźć przyczyny tak surowego potraktowania begardów przez Sobór w Vienne. Dotychczas pojawiło się kilka przekonujących wyjaśnień. Jak się okazuje, co też jest najbardziej zaskakujące, głównym powodem nie były wcale przypadki herezji wśród begardów, żyjących regularnie we wspólnocie. Wiemy bowiem, głównie dzięki wnikliwym analizom J.-C. Schmitta, że stosunkowo niewielu begardów przystąpiło do różnego typu czternastowiecznych ruchów heterodoksyjnych ${ }^{17}$. Ci natomiast, którzy wystąpili ze wspólnoty lub zostali $\mathrm{z}$ niej usunięci, np. z powodu odstępstwa od zasad wiary, przestawali być formalnie begardami i pozbawiani byli wszelkich praw i przywilejów. Dobrym przykładem takiego modus procedendi jest przytoczone wcześniej świadectwo interwencji biskupiej z 1286 roku odnośnie do begardów z Malines. Przypomnę, że na prośbę tamtejszego mistrza biskup zakazał byłym begardom m.in. noszenia stroju świadczącego o wcześniejszej przynależności. Widać zatem wyraźnie, że mistrzowie begardzcy z jednej strony dbali o czystość i legalność swojej obecności w Kościele, a z drugiej mieli świadomość możliwości i zapewne konkretnych sytuacji podszywania się pod ich działalność. Ta ostatnia uwaga otwiera również listę przyczyn, które doprowadziły do ataku na ruchu begardzki.

Już w osiemnastowiecznym zbiorze średniowiecznych źródeł De beghardis et beguinabus commentarius przygotowanym przez Jana Mosheima odnajdujemy wyjaśnienie, że zastosowane przez sobór vienneński postanowienia antyheretyckie sprowokowane były nie przez prawdziwych begardów, lecz przez różnego typu włóczęgów, którzy nie tylko naśladowali begardów w sposobie ubierania się i sposobie życia, ale wprost utożsamiali się z nimi ${ }^{18}$. Do owych fałszywych, wędrownych begardów należy odnieść większość uchwał contra beghardos, które zostały wydane przez niemieckie władze kościelne przed 1311 rokiem. W sławnych statutach mogunckich z 1259 roku odnajdujemy zachętę do walki przeciwko żebrzącym włóczęgom, wołającym charakterystyczne: „Chleb w imię Boga” (Brott durch Got). Faktu, że oni sami uważali się za begardów, nie należy tłumaczyć wyłącznie ich wyjątkową przewrotnością. Mogli być rzeczywiście przekonani, że ich działalność nie tylko mieści się w ramach ruchu begardzkiego, ale jest jego doskonalszą wersją: podobnie jak begardzi regularni, byli oni ludźmi świeckimi, którzy, pozostając w świecie, prowadzili życie jakby zakonne; byli również

${ }_{17}$ Zob. J.-C. Schmitt, Mort d'une hérésie..., s. 66.

${ }_{18}$ [J. L. von Mosheim], Jo[hannes] Laurentii a Mosheim Incluti Georgiae Augustae, Dum in vivis esset, cancellarii De Beghardis et Beguinabus commentarius. Ed. G. L. Martini. Lipsiae 1740, s. $187-188,616-617$. 
wolni od bezpośredniej zależności od władzy duchownej. W odróżnieniu jednak od swego pierwowzoru, posiadali oryginalną i heterodoksyjną teologię, charakteryzowali się niechęcią do instytucji i hierarchii kościelnej oraz częstokroć praktykowali radykalne ubóstwo i inne skrajne formy pobożności. Zatem obok prawdziwych begardów średniowieczne społeczeństwo miało również ich heretycki odpowiednik, innych „begardów”. W tym kontekście trzeba zgodzić się z opinią Marcela Haveralsa, że „Dekret vienneński Ad nostrum qui desideranter świadczy niewątpliwie o trosce o to, by nie tolerować już dłużej wymykających się spod władzy hierarchii niezależnych wspólnot pobożnych laików. W tym sensie sobór vienneński jest punktem zwrotnym"19.

Niezależność begardów i ich autonomia wewnątrz wspólnoty Kościoła stanowiła najbardziej drażliwy element ruchu begardzkiego ${ }^{20}$. Tutaj też należy poszukiwać punktu zapalnego wszelkich konfliktów z duchowieństwem. Begardzi bowiem, nawet jeżeli nie burzyli, to bez wątpienia przekraczali ustalony porządek trzech stanów: duchowieństwa, zakonników i świeckich. Co więcej, na ich niekorzyść, status begardów, o czym powiemy więcej w trakcie omawiania treści dzieła Henryka Harrera, nie był zbieżny z wydawałoby się analogicznym do begardzkiego, ruchem tercjarskim. Trzecie zakony, tak dominikański, jak i franciszkański, posiadały reguły zatwierdzone przez odpowiednie władze zakonne, podlegały ich opiece duszpasterskiej oraz ścisłej kontroli. Ich działalność nie sytuowała się obok działalności zakonów, ale odbywała się w ich ramach. Niewątpliwie brak bezpośrednich więzi z większymi strukturami kościelnymi dawał begardom większą swobodę w kształtowaniu własnego życia wspólnotowego, ale równocześnie rodził atmosferę nieufności oraz podejrzeń o nieortodoksyjność. W tym kontekście nie dziwi fakt, że w sytuacji pojawienia się różnych osób podających się za begardów, prawdziwi begardzi pozostali bez zewnętrznej protekcji i reprezentacji oraz możliwości wyjaśnienia zaistniałych nieporozumień. $\mathrm{W}$ trakcie ataku w XIV wieku pozostali sami na doktrynalnym polu walki, a fałszywi begardzi skutecznie i definitywnie zajęli ich miejsce.

Po Soborze w Vienne zaczęto przyglądać się nie tylko sposobowi życia i doktrynie begardów, ale także etymologii ich nazwy. Już bowiem samo określenie „begard” miało dekonspirować podejrzanych i dowodzić ich nieczystych intencji. Nie musiało bowiem pochodzić ani od staroniemieckiego słowa beggen, czyli modlić się, ani starofrancuskiego bege, oznaczającego kolor niefarbowanej sukni

\footnotetext{
${ }^{19}$ M. Haverals, Trzeci Zakon świętego Franciszka..., s. 149.

${ }_{20}$ Zob. tamże, s. 148.
} 
z surowej wełny noszonej przez begardów ${ }^{21}$, czy też od św. Beggi, córki Pepina Starszego ${ }^{22}$, ale od innego znaczenia słowa beggen, tłumaczonego jako „żebrać”, starofrancuskich przymiotnika begart - „heretycki” lub „fałszywy”, i rzeczownika - begalt, wyjaśnianego jako „leń” lub „głupiec”23, a wreszcie od dwunastowiecznego heretyka Lamberta, noszącego rzekomo przydomek Le Bègue - Jąkały ${ }^{24}$. Jak widać, sama etymologia nie poprawiała wizerunku i wiarygodności begardów, ale raczej dawała ich przeciwnikom skuteczne narzędzie propagandowe.

Jednak tym, co ostatecznie na setki lat wypaczyło postrzeganie ruchu begardzkiego, nie była działalność fałszywych begardów, pejoratywna etymologia, niezależność czy w końcu konflikty z duchowieństwem, ale, paradoksalnie, promulgowany w 1317 roku dekret soboru viennieńskiego. Papież Jan XXII, nie tylko - jak wykazał Robert Lerner - „powołał do życia” herezje wolnego ducha, ale stworzył w rzeczy samej nowy typ ruchu begardów, będący najbardziej pluralistyczną i pojemną herezją średniowiecza ${ }^{25}$ Z czasem bowiem określenie „begard” zaczęło być traktowane jako synonim wyznawców zarówno sekty wolnego ducha, jak i beginów, waldensów, turpilianów, franciszkańskich spirytuałów, a nawet husytów.

Świadectwa takiego szerokiego rozumienia begardyzmu odnajdujemy w licznych tekstach powstałych na przestrzeni całego XIV i XV wieku. Już kilka lat po ogłoszeniu dekretu soborowego, w traktacie zatytułowanym De secta begardorum, biskup Strasburga Jan z Dürbheim przypisał begardom kilkadziesiąt błędów, które bez wątpienia należy związać z herezją wolnego ducha ${ }^{26}$. Podobne utożsamienie występuje w spisanym ok. 1335 roku wyznaniu Jana $\mathrm{z} \mathrm{Brna}^{27}$ oraz aktach procesu pewnego begarda $\mathrm{z}$ diecezji mogunckiej, przeprowadzonego W $1347 \mathrm{roku}^{28}$. Na popularność takiego powiązania begardów z ideologią wolnego ducha wskazują również teksty spoza środowiska inkwizycyjnego, chodzi mianowicie o pochodzące $\mathrm{z}$ drugiej połowy XIV wieku kazania dominikanina Jana

${ }^{21}$ Zob. U. Borkowska, Beginki i begardzi. W: Encyklopedia katolicka. T. 2. Lublin 1976, kol. 177.

${ }_{22}^{2}$ Zob. J. Wyrozumski, Beginki i begardzi..., s. 7.

${ }_{23}$ Zob. J.-C. Schmitt, Mort d’une hérésie..., s. 64.

${ }^{24}$ Zob. P. Poswick, Lambert le Be hérésie..., s. 64. Zob. tenże, Lambert le Bègue et l’origine des béguinages. „Bulletin de la Société d'art et d'histoire du diocèse de Liège” T. 32: 1946, s. 59-73.

${ }_{25}$ Zob. R. Lerner, The Heresy..., s. 78-84.

${ }^{26}$ Zob. Beiträge zur Sektengeschichte des Mittelalters. Ed. I. von Dölinger. T. 2. Münich 1890, s. 389-394, nr 38.

${ }_{27}$ Zob. G. Leff, Heresy..., s. 498-500, 709-715.

${ }_{28}$ Zob. tamże, s. 384-389, $\mathrm{nr} 37$. 
Taulera. Spotykamy w nich kilkukrotnie ostrzeżenia przed „begardami - braćmi wolnego ducha"29.

Jednak, jak trafnie zauważył Robert Lerner, sprowadzenie ideologii fałszywych begardów wyłącznie do herezji „wolnego ducha” jest zbyt daleko idącym uproszczeniem $^{30}$. Warto bowiem zauważyć, że równie popularny był wizerunek „begarda-waldensa". Doskonałym i niezwykle interesującym przykładem jest anonimowy Tractatus de beghardis, będący zapisem listy błędów heretyków sądzonych w Metzu w 1337 roku $^{31}$. Pomimo że postać begarda pojawia się zarówno w tytule, jak i kilkukrotnie w samej narracji, to traktat - jak ustalił Courtney Kneupper - generalnie opisuje doktrynę waldensów z pewnymi elementami poglądów beginów francuskich ${ }^{32}$. Wydawca wprost stwierdzit, że „the word «beghard» appears to be routhly synonymous with our word «heretic»" "3. Begardzi, będący w rzeczywistości waldensami, są również bohaterami dwóch traktatów z drugiej połowy XIV wieku: De erroribus begehardorum, autorstwa Konrada z Megenburga, i Contra hereticos, beckardos, lulhardos et sewestriones Jana Wasmondi z Homburga ${ }^{34}$.

W drugiej połowie XIV wieku zaczęto łączyć begardów z beginami i franciszkańskimi spirytuałami. Pierwsze ślady tej asymilacji odnajdujemy już w bulli Jana XXII Cum de mulieribus z 1 czerwca 1326 roku $^{35}$. Jednak głównym medium, które rozpowszechniło wizerunek begarda, wyznającego radykalne ubóstwo, był podręcznik Mikołaja Eymeryka zatytułowany Directorium inquisitorum ${ }^{36}$. Autor ten w rozdziale rozpoczynającym się do słów: „Heareses et errores Begardorum, Beginorum, Fraticcellorum vel Fratrum de poenitentia de tertio ordine Sancti Francisci" ${ }^{37}$ przepisał dosłownie rozdział z podręcznika Bernarda Gui. Należy wszakże zauważyć, że Bernard rozdział ten zatytułował nieco inaczej: Heareses et errores Beginorum et Fratrum de poenitentia Sancti Francisci $i^{38}$. Nie wspomniał on zatem, zgodnie z prawdą, ani słowem o begardach. Ogromna popularność

${ }^{29}$ J.-C. Schmitt, Mort d'une hérésie..., s. 66.

${ }^{30}$ Zob. R. Lerner, The Heresy..., s. 49.

${ }^{31}$ Zob. C. Kneupper, Reconsidering..., s. 187-225.

${ }^{32}$ Zob. tamże, s. 222.

${ }_{33}$ Tamże, s. 189.

${ }^{34}$ Zob. H. Haupt, Zwei Traktate gegen Beginen und Begharden. „Zeitschrift für Kirchengeschichte" Bd. 12: 1891, s. 85-90.

${ }^{35}$ Bullarium Ordinis Praedicatorum. Ed. Thomas Ripolli. T. 2. Romae 1730, s. 169-170.

${ }^{36}$ Zob. Nicolaus Eymericus, Directorium inquisitorum. Ed. F. Pegna. Venetiis 1607.

37 Tamże, quaestio XV, s. 281-29o.

${ }^{38}$ Bernardus Guidonis, Practica Inquisitionis Haereticae Pravitatis. Ed. C. Douais. T. 1. Paris 1886, s. 108 . 
podręcznika Eymeryka stanowiła ostatni etap w utrwalaniu nieporozumień odnośnie do ruchu begardzkiego. W konsekwencji nic już nie stało na przeszkodzie, by begardami nazwać również przedstawicieli sekty turlipinów, którzy wyznawali ideologie wolnego ducha, a nawet samych husytów ${ }^{39}$. Ta ostatnia asymilacja była szczególnie akcentowana w tekstach polemicznych XV wieku. Miała ona na celu przede wszystkim podkreślenie wybitnie heretyckiego charakteru całego ruchu husyckiego. Na koniec warto wspomnieć o jeszcze jednym dziele Locustarium de sectis, autorstwa franciszkanina Jana Aquentisa. Opisując historię herezji w Czechach, stosował on określenie „begard” zarówno odnośnie do waldensów i husytów, jak i taborytów, adamitów, braci czeskich, a nawet włoskich flagelantów ${ }^{40}$.

W świetle powyższych uwag na temat średniowiecznej herezji begardzkiej, możemy raz jeszcze powtórzyć opinię J.-C. Schmitta, że sami begardzi nigdy nie uformowali sekty, która posiadałaby jakiekolwiek ramy instytucjonalne, czy też jeden zespół charakterystycznych dla niej poglądów. Sekta begardzka istniała wyłącznie jako twór teoretyczny, a nawet retoryczny, który opisywał in generale problem herezji w późnośredniowiecznej Europie. Stąd też mianem begarda można było określić każdą osobę, która głosiła nauki sprzeczne z doktryną Kościoła. Begardem-heretykiem był zarówno żyjący niemoralnie przedstawiciel sekty wolnego ducha, jak i ascetyczny członek ruchu fraticellich, odrzucający sakramenty waldens i utrakwistyczny husyta. Inaczej niż w przypadku klasycznych herezji, sam termin „begard-heretyk" nic nam nie mówi o specyfice jego doktryny i domaga się każdorazowego dookreślenia. W tym celu niezbędna jest zawsze dodatkowa analiza takich danych, jak jego modus vivendi, odniesienie do Kościoła i stosunek do sakramentów. Istnienie wykoncypowanych begardów-heretyków było ściśle zakorzenione $\mathrm{w}$ istnieniu prawdziwych $\mathrm{i}$, co więcej, ortodoksyjnych begardów. Było to jednak swego rodzaju „pasożytnictwo”, które ostatecznie doprowadziło nie tylko do zniekształcenia pierwotnego znaczenia terminu „begard”, ale także do zaniku samego ruchu begardzkiego. Niewątpliwie kolejną dotkliwą konsekwencją połączenia realnych begardów z fikcyjnymi begardami-heretykami było ogromne zamieszanie, jakie mogliśmy obserwować w całej średniowiecznej literaturze ${ }^{41}$.

${ }_{39}$ Zob. J.-C. Schmitt, Mort d'une hérésie..., s. 66-67.

${ }^{40}$ Zob. H. Haupt, Waldensertum und Inquisition im südöstlichen Deutschland. „Deutsche Zeitschrift für Geschichtswissenschaft” R. 3: 1890, s. 338-339.

${ }^{41}$ Skutki tych nieporozumień odnajdujemy także we współczesnej historiografii. W tym miejscu wystarczy wspomnieć tylko o dwóch klasycznych opracowaniach, autorstwa wybitnych 


\section{II}

Wszystkie ze wspomnianych wyżej tekstów przeciwko begardom nie dotyczyły begardów sensu stricto, ale różnego typu średniowiecznych ruchów heterodoksyjnych - od waldensów i flagelantów, a przede wszystkim wyznawców ideologii wolnego ducha. Mając zatem na uwadze poczynione ustalenia, możemy raz jeszcze zapytać, o kim właściwie pisał autor Tractatus contra beghardos, gdy wołał: „Tu vilissime heretice begarde!”?

Nie ulega wątpliwości, że Henryk Harrer usilnie starał się wykazać, że krakowscy begardzi - zgodnie z relacją miejscowych zakonników - są heretykami. Jednak obok gorliwości czeskiego dominikanina w wykazywaniu błędu możemy zauważyć wyraźną powściągliwość w stawianiu „klasycznych” antyheretyckich zarzutów. Nie odnajdziemy zatem oskarżeń o rozwiązłość i nieobyczajność, kontakty z demonami, czy w końcu podejrzane praktyki religijne (tj. czary itp.) ${ }^{42}$. Brak również w traktacie Harrera jakichkolwiek informacji, by krakowscy heretycy należeli do sekty wędrownych waldensów czy też żebrzących beginów. Jednak najbardziej znacząca jest jedna obserwacja - nie byli oni również wyznawcami ideologii wolnego ducha. Warto podkreślić, że Harrer zaledwie w jednym punkcie doszukiwał się analogii pomiędzy opisanymi przez siebie oskarżonymi a begardami-heretykami z dekretu soborowego Ad nostrum. Jednak - jak zobaczymy nieco dalej - porównanie to było raczej chybione. W świetle tych kilku uwag możemy już teraz stwierdzić, że krakowscy begardzi z traktatu Harrera, nawet jeżeli rzeczywiście byli heretykami, reprezentowali ruch, który wyraźne odbiegał od dotychczas opisanych w innych traktatach contra beghardos.

Harrer, przygotowując swój nad wyraz erudycyjny traktat, zastosował klasyczną strukturę właściwą tekstom narracyjnym: rozbudowany prologus, tróje-

polskich badaczy Tadeusza Manteuffla i Stanisława Byliny. Pomimo że kilkukrotnie wspominali o synonimicznym znaczeniu terminu „begard” i „heretyk”, to jednak w toku narracji begardzi-heretycy przedstawiani zostali jako jeden z nurtów begardyzmu. Co więcej, historycy ci przyjęli nie do końca prawdziwy pogląd, że begardzi-heretycy głosili przede wszystkim ideologię wolnego ducha. Zob. T. Manteuffel, Narodziny herezji. Warszawa 1963, s. 114-116; S. Bylina, Wizje społeczne wherezjach średniowiecznych. Wrocław 1974.

${ }_{42}$ Zob. T. Gałuszka, Z warsztatu inkwizytora. Obraz heretyka w świetle „Glossa Ordinaria super Osee contra haereticos" (ADK, RXV.14). W: Inkwizycja papieska w Europie Środkowo-Wschodniej. Pod red. P. Krasa. Kraków 2010, s. 269-293; M. Cetnarowski, Prawda i fałsz w procesie inkwizycyjnym, na przykładzie procesu beginek $w$ Świdnicy w 1332 roku. W: Antyk, prawda i fałsz w średniowieczu. Pod red. J. Kowalskiego, T. Ratajczaka. Poznań 2011, s. 125-130. 
lementowa expositio i w końcu podsumowujący całość wywodu epilogus. Pomimo tej „statycznej” struktury, Contra beghardos posiada wewnętrzną dynamikę. Harrer bowiem zastosował oryginalną formę dyskursu inkwizycyjnego, czyli „dialogu” pomiędzy przedstawicielem Kościoła a osobą oskarżoną o herezję ${ }^{43}$. Oczywiście ta specyficzna "rozmowa” odbywa się na warunkach ustalonych przez autora, będącego równocześnie głównym przesłuchującym. I choć Harrer, zgodnie z charakterem dzieła, przedstawiał oskarżonych $\mathrm{w}$ jak najbardziej negatywnym świetle, to jednak niewątpliwie starał się zachować pewien obiektywizm i uczciwość wobec adwersarzy. Znacząca jest obecność w tekście Contra beghardos takich argumentów i wypowiedzi podsądnych, wobec których czeski dominikanin musiał zastosować mniej lub bardziej udane wybiegi retoryczne. Wydaje się zatem dość prawdopodobne, że Harrer pisząc swój traktat, rzeczywiście miał przed oczyma dokładny opis krakowskiego ruchu świeckich. Zanim przejdę do prezentacji wywodów i opinii naszego dominikańskiego autora, warto w pierwszej kolejność oddać głos samym oskarżonym. W tym celu ograniczę się jedynie do fragmentów, które zawierają bezpośrednie, przytaczane zazwyczaj w mowie niezależnej, wypowiedzi krakowskich begardów.

Głównych bohaterów Contra beghardos nie sposób powiązać z którąś ze znanych średniowiecznych herezji. Co więcej, nie odnajdujemy żadnych dowodów, że poglądy teologiczne, które przyjmowali, były w jakimkolwiek stopniu heterodoksyjne. Oni sami przedstawiali się jako zwykli i prości laicy, którzy nie posiadali ani odpowiedniego wykształcenia, ani wiedzy ${ }^{44}$. Stąd też zarzuty o celową i przemyślaną strategię zniszczenia Kościoła traktowali oni jako kompletne i krzywdzące nieporozumienie. Przyznali jednak wprost, że ich sposób życia w pewnych punktach wyróżniał się na tle praktyk dewocyjnych innych osób świeckich, przy czym cały czas przypominali, że ich działanie motywowane było wyłącznie chęcią budowania społeczności Kościoła, w której wiernie i posłusznie trwają ${ }^{45}$. Potwierdzeniem takiej postawy była choćby przytoczona przez Harrera jednoznaczna deklaracja rzekomego heretyka: „obedio et ad Ecclesiam sicut alter uenio" ${ }^{46}$. Równocześnie jednak potwierdzili obserwacje, że część swojej działalności prowadzili poza murami świątyń. Nie opuszczali jednak wspólnoty

${ }_{43}$ Zob. P. Kras, Ad abolendam..., s. 289-294.

${ }^{44}$ Zob. $C b$, k. $165 \mathrm{r}^{\mathrm{b}}$ : „laycus sum et scripturas non intelligo quomodo ergo errare in tali uita etiam begardorum potui uel potero?".

${ }_{45}$ Zob. tamże, k. $164 \mathrm{~V}^{\mathrm{b}}$ : „Intentio mea non est aliquem tali exemplo corrmupere sed potius edificare; zob. także przyp. 55.

${ }_{46}$ Tamże, k. 164r $\mathrm{r}^{\mathrm{a}}$. 
Kościoła, a jedynie „osoby przewrotne w tej wspólnocie” ${ }^{77}$. Niekiedy, na wzór zakonników, modlili się poza świątynią w "miejscu spokojnym” (quietum locum), lecz wynikało to jedynie z pragnienia pogłębienia osobistej relacji z Bogiem ${ }^{48}$. Oskarżeni podali również szereg argumentów usprawiedliwiających zasadność i konieczność indywidualnej drogi rozwoju duchowego, a co za tym idzie również indywidualnej i cichej modlitwy oraz praktyk pozawspólnotowych. Argumenty odnaleźli zarówno w Biblii, jak i przykładzie świętych ${ }^{49}$, ale nie omieszkali również wspomnieć o innych powodach, jak choćby cisza i brak ewentualnych rozproszeń wynikających z fizycznej obecności innych osób ${ }^{50}$. W dwóch wypowiedziach możemy dostrzec świadectwa ukierunkowania mistycznego w ich duchowości. Oskarżeni szczerze wyznali, że większą korzyść i intensywniejsze przeżycia duchowe przynosi im modlitwa poza murami kościoła i publicznymi nabożeństwami ${ }^{51}$, a nawet Mszą św.5. Zgodnie jednak zaznaczyli, że wszystkie te działania miały na celu wyłącznie poszukiwanie chwały Bożej i rozwijanie osobistej pobożności ${ }^{53}$. Ponadto, wyraźnie podkreślili, że do Eucharystii przystępowali zawsze $\mathrm{z}$ wyjątkową atencją i gorliwością ${ }^{54}$.

Harrer skrupulatnie wynotował liczne wypowiedzi krakowskich podsądnych na temat ich stosunku do kwestii ubóstwa. Jak można się domyślać, skoncen-

${ }^{47}$ Tamże, k. 161v : „Si autem dicitur quod communitatem fidelium non fugiunt, sed peruersos in communitate ut cum peruersis non peruertantur”.

${ }^{48}$ Zob. tamże, k. $163 \mathrm{~V}^{\mathrm{a}}$ : „non fugio Ecclesiam sed quero quietum locum adorandum extra Ecclesiam".

${ }^{49}$ Zob. tamże, k. $162 \mathrm{v}^{\mathrm{a}-\mathrm{b}}$ : „Inuenio tamen singularitatem commendabilem ut mundum hunc fallacem transeam tripliciter: ex doctrina prophetica, ex ueritate euangelica, et ex ratione sanctorum exemplativa. De doctrina prophetica in Ps. CXL 'Singulariter sum ego donec transeam', et in Euangelio Mathei dicitur per Saluatorem 'Cauete autem ab hominibus', ad hoc etiam est exemplum in uita sancti Alexii, qui mundum istum | singularissime transiuit etc.”

${ }^{50}$ Zob. tamże, k. $164 \mathrm{r}^{\mathrm{b}}$ : „Deuotio in multitudine non habet tantam letitiam spiritualiter propter impedientem actum exteriorem corporalem. Et ideo ibi maior tristicia ergo minor deuotio. Hic autem maius gaudium et per consequens maior deuotio. Et allegas pro te quod dicit Gregorius Nissenus libro De homine "Eius risus procedit ex gaudio, ita lacrime et gemitus sunt signa tristitie".

${ }^{51}$ Zob. tamże, k. 164ra' „Extra Ecclesiam et sine institutione populi maiorem habeo deuotionem”.

${ }^{52}$ Zob. tamże, k. $164 \mathrm{~V}^{\mathrm{a}}$ : „Spiritus meus et mens mea extra hoc sacramentum sepissime plus in deuotionem et contemplationem ampliorem rapitur".

${ }_{53}$ Zob. tamże, k. 163vaa: „Nulli ex hoc do dampnum, nec causam dampni querendo Dei gloriam et meam deuotionem".

${ }_{54}$ Zob. tamże, k. $164 v^{\mathrm{a}}$ : „Et si essem presens in Ecclesia ubi agerentur missarum sollempnia et fieret eleuatio corporis Christi, tamen oculos meos ad illud uidendum cum aliis Christiani fidelibus non leuarem, quia me indignum peccatorem reputarem". 
trowanie na rozwoju życia wewnętrznego wpływało również na radykalizację praktyk zewnętrznych. Oskarżeni nie ukrywali, że chcieli prowadzić życie ewangeliczne ${ }^{55}$. Stąd też na pierwszy plan wydobyli konieczność ascezy ${ }^{56}$ oraz praktykowania ubóstwa ${ }^{57}$. Opierając się na kilku wypowiedziach z Contra beghardos, można przypuszczać, że byli zwolennikami raczej radykalnego ubóstwa ${ }^{58}$. Pewne jest natomiast, co Harrer wyraźnie podkreślił, że ich ubóstwo - co mieli potwierdzać sami oskarżeni - było dużo radykalniejsze niż zakonników ${ }^{59}$. W tym porównaniu możemy dostrzec echa kontrowersji i animozji, jakie musiały istnieć pomiędzy krakowskimi zakonnikami a ruchami świeckich.

Prawdopodobnie do uszu rzekomych heretyków z dominikańskiego traktatu dochodziły oskarżenia o przynależność do opisanych w dekrecie Ad nostrum begardów-heretyków. W tekście Contra beghardos odnajdujemy trzy reakcje na tego typu zarzuty. We wszystkich tych przypadkach domniemani heretycy jednoznacznie odcinali się od begardów. Contra beghardos nie dostarcza żadnych precyzyjnych wzmianek na temat wewnętrznej organizacji ich ruchu. Sam Harrer krótko wspomniał, że odróżniają się od innych podobnym strojem i sposobem życia ${ }^{60}$.

Niezwykle istotne, a być może nawet rozstrzygające w odkryciu, kim byli naprawdę bohaterowie dzieła Harrera, są dwa fragmenty. W pierwszym z nich anonimowy obrońca podsądnych stwierdził: „Isti begardi non sunt. Et si iam begardi essent, errores tamen begardorum condempnatos non tenerent" ${ }^{1}$. Powyższa opinia wydaje się wewnętrznie sprzeczna lub co najmniej niejasna: niewątpliwie nie są oni begardami, a równocześnie mogą nimi być, ale nie popełniać błędów

55 Zob. tamże, k. 165v $\mathrm{v}^{\mathrm{b}}$ : „Me docet ueritas euangelica, sacri documenti ratio exemplatiua et ipsius Christi dicentis et eum sequentium uia uita doctrina. Unde hoc faciens non sum dicendus hereticus sed uerus Christi imitator et discipulus. De hiis in Matheo 'Nolite colliciti esse' etc. et infra 'Considerate lylya agri'. Unde hoc faciens sum unus ex illis discipulis, de quibus Luce dicitur 'Asignauit Dominus et alios septuagintam duos discipulos' etc. et infra 'Nichil tuleritis in uia' etc."

${ }^{56}$ Zob. tamże, k. 162r $\mathrm{r}^{\mathrm{b}}$, „Primam ago ut supra, austeram uitam duco, quasi nudis pedibus ambulo et alia carne moderantia facio".

57 Zob. tamże, k. $161 \mathrm{v}^{\mathrm{b}}$ : „Status noster, ut predicatur, status paupertatis, continentie et prime ceterarumque uirtutum, quas extra homines melius et deuotius exerceo”.

${ }^{58}$ Zob. tamże, k. 162r ${ }^{\mathrm{b}}$ : „Secundum Euangelium omnia relinquerimus et nichil habeamus, ideo perfectiores pauperes eis simus”; k. 162ra: „Dicis enim te nullas habere diuitias”.

59 Zob. tamże, k. $161 \mathrm{v}^{\mathrm{b}}$ : „pauperiores sumus quibuscumque religiosis”.

${ }^{60}$ Zob. tamże, k. $163 \mathrm{r}^{\mathrm{b}}$ : „uiderunt istos similes congregatos pari habitu et actu extra Ecclesiam procubare".

${ }^{61}$ Tamże, k. 162v ${ }^{\mathrm{b}}$. 
begardów. Trudność ta staje się w pełni zrozumiała dopiero w świetle pierwszej sekcji niniejszego studium, w którym zostały przedstawione zarówno dzieje uznanych przez Kościół i władze świeckie begardów regularnych, jak i heretyków, których od XIV wieku częstokroć nazywano begardami. Oczywiście, brak jednoznacznego określenia tożsamości oskarżonych nie daje wystarczających podstaw do powiązania ich $\mathrm{z}$ begardami regularnymi, niemniej jednak czyni taką hipotezę prawdopodobną.

Interpretacja ta staje się wiarygodniejsza $\mathrm{w}$ kontekście ostatniej i jednej z najobszerniejszych wypowiedzi oskarżonych, którą - co trzeba już teraz podkreślić - Harrer umieścił na samym końcu swojego traktatu. Czytamy tam: „Tria sunt pro nobis, que non potestis impugnare, quia hec multis nota sunt, ex quibus arguimus primo, quia multi sumus talem statum habentes; secundo in multis locis quasi in maioribus uidelicet Rome et in Colonia et in aliis locis etc.; tertio, quia incipiendo a capite uidelicet domino papa et descendendo usque ad dominos archiepiscopos, episcopos, clericos regulares et seculares, hii enim omnes statum nostrum tamquam pacifice / dissimulant et in nullo nos et nobis similes impugnant uel molestant"62. Twierdzili zatem, że jest ich bardzo wielu, mają siedziby w licznych miejscach i - co najistotniejsze - są akceptowani zarówno przez papieża, arcybiskupów, biskupów i duchowieństwo, jak i osoby świeckie. Podane trzy argumenty miały rozwiewać wszelkie ewentualne wątpliwości co do ich legalności i ortodoksyjności. Z pewnością jednak nie przekonały one ani polskich informatorów, ani Henryka Harrera. Łatwo zauważyć, że przedstawiona tutaj rekonstrukcja sylwetki „begarda” z Contra beghardos nie tylko nie dała podstaw do łatwego udowodniania herezji, ale raczej skutecznie rozwiewała takie przypuszczenia. W tym kontekście próba udowodnienia przez Harrera heretyckiego charakteru krakowskiego ruchu świeckich zasługuje na szczególną uwagę. Niewątpliwie bowiem Henryk stanął przed niezwykle trudnym zadaniem.

Nasz czeski ekspert, po dokładnym przeanalizowaniu poglądów i sposobu życia krakowskich podsądnych, wskazał wszystkie te elementy, które wzbudzały największe wątpliwości i dawały podstawę do oskarżeń o herezję. Swoje obserwacje i zarazem zarzuty przedstawił w postaci trzech obszernych sekcji: odsunięcie się od wspólnoty Kościoła i utworzenie organizacji nielegalnej (singularitas vite); niewłaściwy stosunek do ogólnie przyjętych i uznanych praktyk religijnych (contemptibilitas sacramenti eucharistiae); liczne wady i przewrotne usposobienie (pertinax voluntas).

${ }^{62}$ Tamże, k. 166r $\mathrm{r}^{\mathrm{a}-\mathrm{b}}$. 
Singularitas vite lub też vita singularis jest pierwszym zarzutem, jaki wprost wysunął Henryka Harrer przeciwko bohaterom Contra beghardos. Termin ten już na wstępie wymaga pewnego wyjaśnienia. Nie chodzi tutaj bowiem o jakąś formę życia pustelniczego i samotnego, czy też fizyczne wyizolowanie z lokalnej społeczności (vita solitaria). Dominikanin nie mówi również o życiu bezżennym lub pozbawionym relacji międzyludzkich (np. rodzinnych). Ową singularitas vite należy interpretować jako życie prowadzone poza wspólnotą Kościoła, tj. poza powszechnie przyjętymi strukturami i zwyczajami eklezjalnymi (vita communis). Każdy więc ruch lub aktywność wiernych, które nie posiadały akceptacji wspólnoty Kościoła, w domyśle odpowiednich władz kościelnych, były podejrzane i niebezpieczne ${ }^{63}$. Jak wiadomo, brak prawnej legitymizacji (zatwierdzenie, reguła, konstytucje zakonne itp.) był główną i wspólną cechą wszystkich średniowiecznych herezji ${ }^{64}$. Stąd też nie dziwi fakt, że Harrer otworzył swój traktat obszernym rozdziałem poświęconym właśnie problemowi singularitas vite. Co więcej, na kanwie tego zagadnienia osadza się cała struktura Contra beghardos. W pierwszym rozdziale Harrer starał się udowodnić, że krakowscy podsądni rzeczywiście prowadzą vitam singularem, a zatem są heretykami. Część ta ma wewnętrzną trójelementową strukturę.

Na początku Harrer starał się określić, kim w rzeczywistości są krakowscy begardzi i do jakiego stanu należą. W pierwszej kolejności stanowczo sprzeciwił się sugestiom, jakoby krakowscy begardzi mieli prowadzić życie na wzór zakonników (exemplo religiosorum) ${ }^{65}$. Opierając się na tekście św. Tomasza z Akwinu, dominikanin odrzucił taką możliwość i wyjaśnił, że nie należą oni do żadnej z czterech form życia zakonnego uznanego przez Kościół: nie są zakonem czynnym, gdyż nie posiadają żadnej wspólnej własności; nie są członkami zakonów rycerskich, gdyż nie prowadzą żadnych wojen, z wyjątkiem walki przeciwko duchowieństwu i prawdziwym zakonnikom; nie są zakonem apostolskim, gdyż zamiast budować głoszeniem, zwodzą swoimi słowami i prowadzą wiernych chrześcijan do potępienia; w końcu nie są również zakonem kontemplacyjnym, gdyż nie są oddzieleni od ludzi i nie żyją w samotności ${ }^{66}$. Harrer doprecyzował jeszcze

${ }^{63}$ Zob. tamże, k. 163r $\mathrm{r}^{\mathrm{a}}$ : „Ymmo totum quidquid est preter Ecclesie ordinationem uel contra consuetudinem communem, uidelicet esse supersticiosum et superfluum in diuino cultu".

${ }^{64}$ Zob. J.-C. Schmitt, Mort d’une hérésie..., s. 111-113.

${ }^{65}$ Zob. tamże, k. 161ra' „Si dicitur 'exemplo religiosorum' dico, quod religiosi non sunt”.

${ }^{66}$ Zob. tamże: „Et scriptum est hoc dictum ex Euangelio Mathei, quod etiam patet ad sensum. Nam secundum sanctum Thomam, qui supra, eodem libro quo supra, questione CXXXVII, diuersa capitula, propter quas causas diuerse religiones sunt institute, quia quedam ad opera uite actiue, 
powyższą typologię i zaznaczył, że oskarżeni nie są również pustelnikami, gdyż „[... se tota die hominibus ostendunt et exhibent; etiam si se includant, conuenticula circa se faciunt" 67 . Zdaniem czeskiego dominikanina krakowscy oskarżeni nie tylko nie prowadzili życia na wzór zakonników, ale również - wbrew własnym deklaracjom - nie byli członkami stanu świeckiego ${ }^{68}$. Opinia ta nie została poparta żadnym konkretnym argumentem, jak choćby oskarżeniami o odrzucanie małżeństwa czy stworzenie osobnej organizacji religijnej. Czeski dominikanin ograniczył się wyłącznie do zaakcentowania dwóch cech, o których wspominali sami oskarżeni, a które wyróżniały ich z ogółu wiernych świeckich - radykalizm w praktykowaniu ubóstwa i podjęcie szeroko rozumianej indywidualnej drogi życia duchowego. Drugiemu zarzutowi Harrer poświęcił cały drugi rozdział Contra beghardos.

Oskarżeni, przyznając się do radykalnego ubóstwa, dostarczyli Harrerowi jednego z najmocniejszych dowodów przeciwko ortodoksyjności swojego ruchu. Należy przypomnieć, że temat ten w latach dwudziestych i trzydziestych XIV wieku, a zatem w momencie powstawania Contra beghardos, był żywo dyskutowany w ówczesnym Kościele. Chodziło o sławny spór o rozumienie ubóstwa zakonnego, jaki zaistniał pomiędzy papieżem Janem XXII i grupą franciszkanów ${ }^{69}$. Ci ostatni, zwani również „spirytuałami”, interpretowali zalecenia św. Franciszka w sposób radykalny i postulowali wyrzeczenie się posiadania

quedam ad bella gerenda, quedam ad predicandum, quedam ad contemplandum etc. Quod horum hii faciant uideamus. Si dicatur uitam actiuam gerere, respondeo, quod hoc non faciunt, quia se nichil habere predicant et dicant. Si autem dicatur bella gerere, uerum est suo modo, contra religiosos et clerum, quibus se preferentes uitam et doctrinam eorum et maxime simplicium et malorum quantum possunt aput multos homines deducunt in contemptum. Si dicantur predicare, hoc uerum est in eorum conuenticula de facto non de iure, cum ad hoc non sint missi, nisi ut satellites dyaboly et angeli sathane multos decipientes. Si dicantur contemplatiui, dico posse ipsos esse fictos contemplatiuos, quare uita contemplatiua est soli Deo uocare et inter homines et cum hominibus non multum occupari”.

${ }^{67}$ Tamże.

${ }^{68}$ Zob. tamże, k. 163v': „Item laycy non sunt, quia communem uitam laycorum ab Ecclesia approbatam, quam Christus uerbo et exemplo docuit, fugiunt et fastidiunt. Quod lamentabile est, congregatos in unam communem uitam et collectos Christi sanguine, uelut lupi rapaces oues eiusdem Christi dissipant et dispergunt".

${ }^{69}$ Literatura nt. sporu Jana XXII z franciszkanami i rozumienia ubóstwa jest bardzo obszerna zob. szczególnie: D. Burr, The Spiritual Franciscan. From protest to persecution in the century after Saint Francis. Pennsylvania 2001; P. Nold, Pope John XXII and his Franciscan Cardinal. Bertrand de la Tour and the apostolic poverty controversy. Oxford 2003; tenże, Pope John XXII 's Annotations on the Franciscan Rule. Content and Contexts. „Franciscan Studies” T. 65: 2007, s. 295-324; J. Łopat, 
wszelkiej własności. Jan XXII postanowił zapobiec grożącemu podziałowi owego Zakonu i w tym celu podał papieskie rozumienie franciszkańskiego ubóstwa, które miało być rozstrzygające dla całego Kościoła. 8 grudnia 1322 roku papież ogłosił konstytucję Ad conditorem canonum, w której to stwierdzał, że Stolica Apostolska zrzeka się dóbr Zakonu Braci Mniejszych i zwraca je, czyniąc w ten sposób franciszkanów pełnoprawnymi właścicielami ruchomości i nieruchomości. Zniósł również instytucję syndyków papieskich, którzy owymi dobrami zarządzali. Takie posunięcia papieża spotkały się ze zdecydowanym sprzeciwem ze strony radykalnej części Zakonu. W odpowiedzi papież 12 listopada 1323 roku wydał kolejną konstytucję Quum inter nonnullos, w której stwierdzał, że uparte twierdzenie, iż Chrystus i apostołowie nie posiadali niczego osobiście ani wspólnie, jest herezją. Tymczasem zamiast załagodzić kontrowersje, konstytucja została skrytykowana. Franciszkanie sprzymierzyli się z wrogiem Jana XXII - cesarzem Ludwikiem Bawarskim. 22 maja 1324 roku w Sachsenhausen wydał on dekret, który zawierał m.in. zarzuty Braci Mniejszych wobec wspomnianych konstytucji, a papieża nazywał heretykiem. Wobec takiego obrotu spraw 13 listopada 1324 roku papież wydał kolejną bullę Quia quorundam, w której bronił argumentów zawartych w Ad conditorem i Quum inter nullos i zakazywał dalszej krytyki pod sankcją ekskomuniki ${ }^{\circ}$. Bulla Quia quorundam została również explicite przytoczona przez Harrera i stanowiła podstawę prawną do oskarżenia krakowskich begardów o herezję. Pisał on: „Dic ergo, uilissime heretice begarde, que tua paupertas, cum nichil habeas in proprio nec in communi sicut Christus et eius apostoli, si sic, incides in dampnatam heresym per constitutionem 'Quia quorundam', quia nullus ut tibi uidetur similis est in paupertate"71. $Z$ wypowiedzi podsądnych, jakie odnajdujemy w Contra beghardos dowiadujemy się jedynie, że praktykowali oni skrajne ubóstwo ${ }^{72}$. Brak natomiast informacji, by, na wzór franciszkańskich spirytuałów, wyznawali oni heterodoksyjne poglądy na temat

Wilhelma Ockhama „Opus nonaginta dierum” jako epigońska i desperacka obrona ideału franciszkańskiego ubóstwa w XIV wieku. „Lignum Vitae” T. 10: 2009, s. 11-58.

7o Warto zauważyć, że w tym dokumencie pojawiają się również dominikanie, jako przykład dobrze rozumianego i praktykowanego ubóstwa. Czytamy tam m.in. Extravagantes Ioanni, tit. XIV, c. V (Corpus Iuris Canonici. Ed. E. Friedberg. T. 2. Graz 1956, s. 1234): „Praedicatores Christum pauperem imitari, ipsosque perfectionem evangelicam amplexari, et in statu exsistere perfectorum, quodque ipsorum religionis observantia perfectionis evangelicae tenet formam; et tamen constat, ipsos habere posse etiam quoad proprietatem aliqua iuxta eorum regulam in communi".

${ }^{71} \mathrm{Cb}, \mathrm{k} \cdot 162 \mathrm{r}^{\mathrm{a}}$.

${ }^{72}$ Zob. przyp. 58. 
ubóstwa Chrystusa i Jego uczniów. Harrerowi wystarczyło to mało precyzyjne wyznanie i w dalszej części swojego traktatu czytelnik otrzymał długi wywód na temat właściwego rozumienia ubóstwa. Przy okazji omawiania tego problemu Harrer szeroko odniósł się do zawartej implicite opinii „heretyków” na temat realizacji ślubów ubóstwa przez zakonników. Autor Contra beghardos, osobiście dotknięty krytyką, zbył milczeniem jakąkolwiek dyskusję nad ówczesną rzeczywistością i od razu przeszedł na poziom teologii życia zakonnego. Przytoczył on liczne autorytety (Biblia, św. Tomasz z Akwinu, św. Bazyli, św. Benedykt z Nursji, prawo kanoniczne), które miały uwiarygodniać i definitywnie potwierdzić następującą tezę - ubóstwo zakonne jest najdoskonalszym sposobem życia ewangelicznego. Co ciekawe, wzorem ubóstwa par excellence - zdaniem Harrera - był św. Franciszek z Asyżu, przy czym nie w wersji promowanej przez radykalnych franciszkanów, ale tzw. interpretacji umiarkowanej, która została ogłoszona przez papieża Bonifacego VIII ${ }^{73}$. W ten sposób dominikanin przeciwstawił praktykę ubóstwa krakowskich oskarżonych zwyczajom i tradycji Kościoła. Ponadto, krytyka ubóstwa zakonnego ze strony „begardów” została w Contra beghardos poniekąd utożsamiona $\mathrm{z}$ atakiem na ortodoksję. Trzeba jednak zaznaczyć, że autor nie przytoczył ani jednej wypowiedzi oskarżonych, w której moglibyśmy odnaleźć informacje o próbach podważenia, choćby niejawnie, wiarygodności hierarchii kościelnej. Obserwacja ta jest o tyle istotna, że oskarżenia o antyklerykalizm były stałym punktem dyskursu antyheretyckiego i jedną z głównych cech średniowiecznych herezji ${ }^{74}$.

W ostatniej części pierwszej sekcji Contra beghardos Harrer zmierzył się z chyba najtrudniejszym stwierdzeniem dotyczącym krakowskich „begardów”, a mianowi-

${ }_{73}$ Zob. $C b, \mathrm{k} .161 \mathrm{v}^{\mathrm{b}}-162 \mathrm{r}^{\mathrm{a}}$ : „Hoc etiam dicit Augustinus in regula clericorum, que est hodie regula omnium religiosorum exceptiis hiis, qui uiuunt sub regula Basilii, Santi Benedicti et Santi Francisci, ex qua regula sancti Francisci ueritas de paupertate religiosorum ut est supra dictum. Nam idem almus confessor et | egregius mundi contemptor, quem filius Dei per supremum angelum, uidelicet de seraphin, suis stigmatibus signare uoluit, predicans suam regulam in artissima paupertate fundauit, ut hec uerba in regula predicta clarissime ponuntur et leguntur, quam paupertatem admoderamine exposuit summus pontifex Bonifacius in Christo pater sanctissimus, libro III, extrau. 'De uerborum significatione', paragrapho 'Nec quicquam', ubi sic 'Nec quicquam insurgat erroneum, quod taliter propter Deum proprietatem omnium abdicantes, tamquam homicide sui uel temptatores Dei, uiuendi discrimini se committant' etc."

74 Zob. P. P. Młynarczyk, Terra ecclessiae. Najazdy zbrojne na dobra kościelne na Śląsku w końcu XIII i na poczatku XIV wieku. W: Profanum versus sacrum. Przejawy postaw antykościelnych w Polsce na przestrzeni wieków. Pod red. A. Gotowicza, R. Koteckiego, J. Maciejewskiego. Bydgoszcz 2011, s. 59 . 
cie, że „Oni nie są begardami. A nawet gdyby byli begardami, to mimo to nie trwają w godnych potępienia odstępstwach begardów"75. Harrer natychmiast dostrzegł tutaj wyraźną - choć jak wiemy, pozorną - niespójność, dlatego też oba zdania poddał osobnej i niezależnej analizie. $\mathrm{W}$ odniesieniu do pierwszego dominikanin zarzucił oskarżonym kłamstwo i wskazał na ich czyny, które wbrew deklaracjom, niezbicie dowodzą ich przynależności do ruchu begardzkiego. Prymat czynów nad słowami w poszukiwaniu prawdy potwierdził autorytetem świętych: Augustyna, Tomasza z Akwinu, Ryszarda ze św. Wiktora i w końcu - Arystotelesa ${ }^{76}$. W przypadku drugiego zdania dominikanin przypomniał, że w przytaczanym już dekrecie Ad nostrum zostało jasno zdefiniowane, że każdy begard jest heretykiem. A zatem, kontynuuje Harrer, nie można popełniać błędów begardów i równocześnie twierdzić, że się nie jest begardzkim heretykiem ${ }^{77}$. Niewątpliwie, ta logiczna sprzeczność musiała dziwić czeskiego dominikanina. Była bowiem albo dowodem ich intelektualnego ograniczenia, albo przeciwnie, ich wyjątkowej przewrotności. Harrer, jak pokazują dalsze części Contra beghardos, wybrał drugą opcję.

Drugim głównym zarzutem wobec bohaterów Harrerowego dzieła było ich rzekome lekceważenie sakramentu Eucharystii (sacramenti eukaristie contemptibilitas). Podstawą do wysunięcia tak mocnych oskarżeń były wspomniane już wypowiedzi samych podsądnych, w których przyznali się do praktykowania modlitwy indywidualnej i cichej poza murami świątyń. Ponadto, szczerze wyznali,

75 Zob. przyp. 61.

${ }^{76}$ Zob. Cb, k. $162 \mathrm{v}^{\mathrm{b}}-163 \mathrm{r}^{\mathrm{a}}$ : „Contra hoc sic respondeo. Contra primum, uidelicet de nomine begardorum non se negant esse begardos. Et tamen eorum habitus et actus et opera realiter eos hoc esse ostendunt. Nam secundum Augustinum De uerbis Domini 'Non uerba rebus, sed res uerbis preponuntur'. Et sanctus Thomas in declarationibus questionum ad Gelardum 'Vanum est contendere de nominibus ubi constat de rebus'. Unde insipienter est credere nominibus et non rebus ut exemplificat Rychardus De Trinitate de herba nocente. Hinc apparet ex rebus. Item uita eorum sic manifestatur habens omnimodam speciem begardorum. Utrum eorum sermonibus uel operibus sit credendum uide. Nam Philosophus libro Ethicorum 'Ex operibus sermones iudicantur', ubi Commentator 'Quod res faciunt credibiles sermones et non e conuerso'. Sic ergo ostendo plus credendum operibus quam nominibus. Et ideo de nomine non multum disputo sed de re, quia supra dico eos habere | realiter speciem, habitum, et actum begardorum”.

77 Zob. tamże, k. 163ra: „Ad secundum, cum dicitur si begardi sunt, tamen errores condempnatos per Ecclesiam cum errantibus non sentiunt. Ad hoc respondeo, quod decretale, de quo supra in Clementina per capitulum 'Ad nostrum'. Intelligimus diuisim uel coniunctim esse facta. Si diuisim tunc habeo intentum, quia omnis begardus est hereticus. Si autem coniunctim tunc quero, si aliquis non existens begardus teneret omnes illos errores, ibidem condempnatos uel unum ex eis. Dic esset talis hereticus?". 
że wybrana przez nich droga rozwoju duchowego ma większą wartość od wspólnych zgromadzeń w Kościele. Dla Harrera powyższe stwierdzenia byłnie tylko ewidentnym dowodem porzucenia przez krakowskich heretyków vita communis, ale również świadectwem niewłaściwego stosunku do Eucharystii.

Harrer skoncentrował się na wykazaniu, że jedynym właściwym miejscem modlitwy jest świątynia i ściśle określone nabożeństwa w Kościele, wśród których najważniejsza jest oczywiście Eucharystia. Wszelkie zaś inne praktyki dewocyjne, które odbywałyby się w innym miejscu, zostały uznane za podejrzane i niebezpieczne, co też nasz autor potwierdził odpowiednimi autorytetami. Na pewno zaś, jak zaznaczył Harrer, wprowadzają podział we wspólnocie wiernych i są główną przyczyną zgorszenia ${ }^{78}$. Według dominikanina źródeł takiego postępowania jest przynajmniej kilka. Na pierwszym miejscu postawił on lekceważący stosunek oskarżonych do tradycji liturgicznej Kościoła, w której modlitwa wspólnotowa oraz publiczna i głośna zajmuje istotne miejsce ${ }^{79}$. Ponadto, praktyki krakowskich begardów - zdaniem dominikanina - musiały być skutkiem nieposłuszeństwa względem urzędu biskupa i papieża ${ }^{80}$. Autor Contra beghardos nie wykluczył również, że podsądni skrycie kwestionują zarówno realną obecność Chrystusa w Eucharystii ${ }^{81}$, jak i miejsce kapłana w sakramentalnym życiu Kościoła ${ }^{82}$. Wbrew jednak własnym przypuszczeniom, przytoczył zaraz inną wypowiedź oskarżonych, w której nie bez zdziwienia dowiadujemy

${ }^{78}$ Zob. tamże, k. 163V multos fideles per hoc trahis et in penas incidis, Euangelium Mathei XVIII, ubi sic 'Ve mundo a scandalis', ubi Glossa 'Scandalum est dictum uel factum minus rectum prebens aliis occasionem ruine'. Responde et dic: non est scandalum actiuum sed passiuum. Ad quod ego dico quod actiuum dans dampnum Christi fidelibus et Ecclesie contemptum et causam dampni”.

79 Zob. tamże, k. 163v $\mathrm{v}^{\mathrm{a}}$ : „Respondeo, aut credis quod laus uocalis in qua laude nomine Domini Ihesu et alia sunt ad deuotionem et ea, que supra, aut non. Si non credis hereticus es”.

${ }^{80}$ Zob. tamże, k. 163v $\mathrm{v}^{\mathrm{b}}$ : „Dic utrum tenearis Ecclesie obedire communi modo uiuendo, Ecclesiam aliis locis excellentiorem, ut supra dictum est, uenerando, an non? Si dicis non, credo <quod $>$ hereticus es et omnibus uirtutibus cares. Nam secundum Gregorium ultimo libro Moral. 'Obedientia sola uirtus est que uirtutes ceteras inserit insertasque custodit'. Et maxime obedientia Ecclesie et summi pontificis est implenda”; k. 164ra : „Et sic preceptum Ecclesie et summi pontificis et communem modum uiuendi fidelium, sequendo tuam uesaniam non obedientiam, contempnis et dimittis".

${ }^{81}$ Zob. tamże, k. 164v $v^{\mathrm{a}}$, „Respondeo aut credis hic esse totum Christum uerum Deum et hominem, nichil ante hoc esse, sicut nec panem ita et nec paneitatem, aut non. Si non credis hereticus es. Si autem credis quomodo dicis quod mens et spiritus tuus extra hoc sacramento plus rapiatur quam in hoc sacramento et circa presentiam huius sacramenti".

${ }^{82}$ Zob. tamże, k. $164 \mathrm{v}^{\mathrm{b}}$ : „An forte tu etiam non credis quod presentia sacerdotum, quos in corde tuo uilipendis, tibi conferat ad deuotionem dum in Ecclesia missarum sollempnia aguntur". 
się o ich szczególnej pobożności eucharystycznej: „Et si essem presens in Ecclesia ubi agerentur missarum sollempnia et fieret eleuatio corporis Christi, tamen oculos meos ad illud uidendum cum aliis Christiani fidelibus non leuarem, quia me indignum peccatorem reputarem. Et ex hoc essem laudandus non uituperandus" ${ }^{\prime 3}$. Tym, co wyraźnie zaniepokoiło Harrera, były słowa oskarżonych o „niepodnoszeniu oczu w czasie podniesienia Hostii”. Wyznanie to przywołało mu na myśl ostatni ósmy punkt dekretu Ad nostrum, który też przytoczył prawie dosłownie: „Sed ut probatum et inuentum est in secta begardorum, id est hereticorum existentium in Ecclesia, oculos ad eleuationem corporis Christi non eleuabant. Causam huius habens in Clementina per capitulum 'Ad nostrum', ubi sic, insunt uerba Begardorum 'In eleuacione corporis Iesu Christi homo non debet assurgere, nec eidem reuerenciam exhibere, asserentes, quod esset imperfectionis eisdem, si a puritate et altitudine sue contemplacionis tantum descenderet, quod circa ministerium seu sacramentum eukaristie, aut circa passionem humanitatis Christi aliqua cogitarent" ${ }^{84}$. Łatwo zauważyć, że zestawienie obu tekstów było kompletnie nieuprawnione: $\mathrm{w}$ wypowiedzi podsądnych chodziło o „niepodnoszenie oczu z powodu własnej grzeszności i szacunku dla Hostii”, a w dekrecie „o niewstawaniu z powodu własnej bezgrzeszności i braku szacunku dla Hostii”. W tym miejscu, chcąc zrozumieć przyczyny zaistnienia tej „nieszczęśliwej nadinterpretacji”, możemy wyłącznie zacytować biblijne słowa: „Ira enim viri iustitiam Dei non operatur” (Jk 1, 20).

Kończąc prezentację drugiej sekcji Contra beghardos, warto zasygnalizować jeszcze jedno zagadnienie, która pojawia się $\mathrm{w}$ trakcie lektury drugiej sekcji Contra beghardos. W przytoczonych przez Harrera wypowiedziach oskarżonych wielokrotnie pojawiały się informacje na temat ich pragnienia osobistej relacji z Bogiem, ciszy i indywidualnej drogi rozwoju duchowego. Równocześnie zaś - inaczej niż członkowie różnych ruchów heterodoksyjnych - trwali we wspólnocie z Kościołem i prowadzili regularne życie sakramentalne. To ukierunkowanie mistyczne odsyła nas bezpośrednio do nowych form pobożności świeckiej, które pojawiły się w Kościele na przełomie XIII i XIV wieku. Chodzi tutaj przede wszystkim o opisane już legalne wspólnoty beginek i begardów. To właśnie w tych środowiskach, głównie żeńskich beginażach, od lat dwudziestych XIV wieku entuzjastycznie przyjmowano oryginalne teksty teologiczne autorstwa dominikanina Eckharta z Hochheim, znanego powszechnie jako

\footnotetext{
${ }_{33}$ Tamże, k. $164 \mathrm{r}^{\mathrm{a}}$.

${ }^{84}$ Zob. tamże, k. $164 \mathrm{v}^{\mathrm{b}}$.
} 
Mistrz Eckhart ${ }^{85}$. One też stanowiły główne źródło aspiracji do mistycyzmu ${ }^{86}$. Niecały rok po śmierci dominikańskiego teologa, 27 marca 1329 roku papież Jan XXII w bulli In agro dominico zakwestionował prawowierność 26 twierdzeń pochodzących z jego dzieł" ${ }^{87}$. W konsekwencji od tej pory także zwolennicy Eckhartowskiej teologii mistycznej znaleźli się w polu zainteresowań inkwizycji ${ }^{88}$. Harrer w swoim Contra beghardos nie odnosi się ani słowem do tych kontrowersji. Z pewnością natomiast musiał znać głośną w całym zakonie sprawę Mistrza Eckharta oraz - jako ekspert w procesach in causa fidei - samą treść dokumentu papieskiego. Fakt, że w trakcie całej „debaty” z krakowskimi oskarżonymi nie sięgnął do żadnego z zawartych tam kilkudziesięciu twierdzeń, można próbować wyjaśnić $\mathrm{w}$ dwojaki sposób: 1) potępione w bulli twierdzenia były wybitnie spekulatywne, natomiast Harrer preferował dyskusje praktyczne wokół problemów prawno-dyscyplinarnych; 2) traktat Contra beghardos powstała przed marcem 1329 roku, co dodatkowo potwierdzałoby hipotezę powstania tego dzieła w latach $1328-1329^{89}$. Niestety, powyższa trudność na razie musi pozostać bez rozstrzygnięcia.

Trzecią i zarazem ostatnią sekcję Contra beghardos Henryk Harrer zbudował wokół problemu pertinax voluntas, którą mieli się odznaczać krakowscy oskarżeni. Owa „oporna wola” zdaniem dominikanina wyrażała się najpełniej w opisanym wcześniej odejściu ze wspólnoty Kościoła. Tym razem jednak wyrażenie singularitas vite zastąpił innym sformułowaniem: divisio vitae ${ }^{9 \circ}$. Zabieg ten miał na celu zainicjowanie nowej kwestii: Czym jest w istocie herezja? Oprócz przytoczenia klasycznej definicji herezji, zaczerpniętej z Sentencji Piotra Lombarda

${ }^{85} \mathrm{Nt}$. recepcji myśli Mistrza Eckharta zob. szczególnie dwie monografie: S. Jäger, Meister Eckhart - ein Wort im Wort: Versuch einer theologischen Deutung von vier deutschen Predigten. Berlin 2008; F. J. Schweitzer, Meister Eckhart und der Laie: ein antihierarchischer Dialog des 14. Jahrhunderts aus den Niederlanden. Berlin 1997.

${ }^{86}$ Zob. G. d 'Onofrio, Historia teologii. T. 2. Przeł. W. Szymona. Kraków 2005, s. 500: „Za pomocą głębokiej i wzniosłej refleksji spekulatywnej teksty Eckharta stwarzały możliwość transpozycji powołania ewangelicznego na głębokie wewnętrzne doświadczenie mistycznego kontaktu z Bogiem".

${ }^{87}$ Zob. R. E. Lerner, New Evidence for the Condemnation of Meister Eckhart. „Speculum” T. 72: 1997, s. 345-366.

${ }^{88}$ Zob. F. J. Schweitzer, Meister Eckhart und der Laie..., s. XLII-L.

${ }^{89}$ Zob. T. Gałuszka, Źródło na nowo odkryte, [w druku].

${ }_{90}$ Zob. Cb, k. $165^{\text {ra }}$ : „Nam secundum Augustinum De Trinitate 'Pertinacia est uicium, quo quisquem suum defendit errorem. Sed dic tu begarde uel fautor tuus dicat pro te 'quem errorem defendo?'. Respondeo, diuisionem uite, qua diuisus es, ut supra dictum est, a communi uita fidelium". 
(„Heresis diuisio interpretatur”), odwołał się do inspirowanej Augustynem tomistycznej doktryny na temat podwójnego charakteru herezji, tj. wymiaru materialnego i formalnego ${ }^{11}$. Autor Contra beghardos wyjaśnił krótko: „Unum est error in ratione quod est heresis inicium; alter in pertinacia in uoluntate quod est heresis complementum"92. Błędny zatem pogląd na temat prawd wiary nie jest jeszcze złem najgorszym. Dopiero upór w błędzie czyni błądzącego heretykiem. Błędy in ratione krakowskich podsądnych zostały - zdaniem Harrera - precyzyjnie i przekonująco wykazane $\mathrm{w}$ dwóch poprzednich sekcjach, teraz natomiast pozostało zmierzyć się z najtrudniejszą przeszkodą - pertinax voluntas ${ }^{93}$. W tej materii dominikaninowi pozostało tylko nawoływać do nawrócenia oraz przedstawić kolejne argumenty.

Wszystkie jednak podjęte przez niego próby okazały się daremne. Oskarżeni definitywnie sprzeciwili się twierdzeniom Harrera o ich rzekomym kacerstwie i jako usprawiedliwienie swojego „uporu” i nieustępliwości podali przytaczane już wcześniej trzy argumenty ${ }^{94}$. Przekonywali oni, że grupa ich była bardzo liczna; posiadali siedziby w kilku europejskich miastach tj. Kolonia i Rzym; a wreszcie - co wyznali z nieukrywanym triumfem - byli akceptowani przez władze kościelne i świeckie. Henryk umieścił ten fragment na samym końcu omawianej trzeciej części Contra beghardos. Czyżby zatem uznał te argumenty za koronny dowód potwierdzający ich przewrotność i zakłamanie? Jeżeli rzeczywiście tak było, to trudno zrozumieć pozostawiającą duży niedosyt odpowiedź Harrera. W przypadku dwóch pierwszych argumentów czytelnik otrzymał obszerny wywód, który może i osłabiał stanowisko krakowskich oskarżonych, lecz z pewnością nie był rozstrzygający ${ }^{95}$. Co się zaś tyczy trzeciego argumentu,

${ }_{91}$ Zob. Thomas de Aquino, In Sent., lib. I, d. XXXIII, q. 1, a. 5, resp. (Ed. P. Mandonnet. T. 1. Parisiis 1929, s. 777); Sth I. q. 32, a. 4 (Editio Leonina. T. 4. Romae 1890, s. 357); Sth II-II. q. 5, a. 3 , resp. (Editio Leonina. T. 8. Romae 1895, s. 58).

${ }_{92} \mathrm{Cb}, \mathrm{k} .165 \mathrm{r}^{\mathrm{a}}$.

${ }_{93} \mathrm{Na}$ temat znaczenia pertinacia w herezjologii i procesach in causa fidei zob. S. Prowidente, „Factum hereticale, representatio et ordo iuris”. Le procès contre Jean Hus au Concile de Constance (1414-1418). „Temas medievales” T. 17: 2009, s. 108-109, przyp. 18-19.

94 Zob. przyp. 62.

${ }_{95}$ Zob. $C b$, k. 166r $\mathrm{r}^{\mathrm{b}}$ : „De primo Ieronimus contra Ruffinum exponens illud enigma Aristotelis 'Per uiam publicam non progrediaris, id est multorum errores non sequaris', quia prima questione II dicitur 'Quod non minus ardet qui cum multis ardet'. Ex hoc enim argumento ualde te reddis suspectum quia ut Crisostomus super Matheum dicit 'Quod ratione uincere non potuerunt, multitudine deuincere uoluerunt'. Et hoc dicitur de phariseis, saduceis et de Christo contra quem in unum conuenerunt, ut 'Ipsum caperent in sermone' etc. Quod autem dicis 
w którym begardzi przypomnieli, że posiadają akceptację samego papieża (!), dominikanin zrezygnował z wyjaśnienia i z irytacją stwierdził: „dicam unum dictum et non plus et est uerbum iuris 'Parum iura condere nisi, qui ea defendat exsistenter"'96. Trzeba zauważyć, że Harrer w żaden sposób nie zakwestionował prawdziwości tego ostatniego argumentu, a przytoczona sentencja wydaje się być nie tyle przemyślaną i celną ripostą, ile wyrazem jego bezsilności wobec braku zdecydowanej i konsekwentnej reakcji prawodawców, czyli Kościoła i władz świeckich.

W tym miejscu uzasadnione jest postawienie dwóch ostatnich pytań, które mają kluczowe znaczenie dla naszego studium: Czy pominięcie tak istotnego dowodu, jakim było stwierdzenie formalnej legalności badanego ruchu nie podważało w ogóle wiarygodności całego „aktu oskarżenia”, czyli Tractatus contra beghardos? Czy milczenie Harrera, nawet w perspektywie wcześniejszych długich i wielowątkowych wywodów, nie było de facto potwierdzeniem niewinności krakowskich podsądnych? Biorąc pod uwagę wszystkie poczynione obserwacje, odpowiedź na obie kwestie może być jedynie pozytywna.

\section{Zakończenie}

Henryk Harrer podejmując się napisania traktatu Contra beghardos, musiał być świadomy, że mierzy się z tematem nadzwyczaj trudnym. Krakowscy dominikanie przekonani byli o heretyckim charakterze działalności pewnej części swoich wiernych, z kolei tutejsza hierarchia wyraźnie wstrzymywała się przed

te multitudine locorum de quibus supra, quero a te utrum credis quod secundum Augustinum De Trinitate Ecclesia habere figuram arche Noe, que animalia munda et immunda in se habeat et hec multitudo animalium, uidelicet hominum in Ecclesia debet esse ex fide et karitate, de hoc in decretis, distinctione XXIII 'Loquimus' et item questione item 'Multe' et XXIIII, questione item 'Loquitur', ubi sic 'Ecclesia katkolica dicitur fidelium Christi multitudo fide et karitate' etc. Et in hac multitudine tu latens heretice begarde Rome et in Colonia et ubique aliunde ostendis. Et aliud inter Christi fideles existis et sic multos te oculos rationis non uidentes fallis et nequiter decipis. Vel ut uulgariter dicitur quod mentientes solent allegare antiqua remota et ignota ut eis in mendaciis possint reprehendi. Sic et tu allegas. Absentia et absentes cum tibi nullis nisi tu tibi in persona tua obiciatur. Sed tu oblitus tui aduocatus uis esse coloniensis gebardi heretici uel romani, ne attendis dictum Socratis in suis exhortationibus te exhortantis, ubi sic 'Age sic alienum ut tuum non obliuiscaris negotium' etc."

${ }_{96}^{6}$ Tamże. 
formułowaniem tak jednoznacznych oskarżeń. W tej sytuacji dominikanie zaangażowali czeskiego eksperta, który niewątpliwie zrobił wszystko, by potwierdzić obawy polskich współbraci. W tekst swojego wywodu włączył szereg wypowiedzi krakowskich podejrzanych, które - pomimo ewidentnej interwencji redakcyjnej autora - najprawdopodobniej odzwierciedlały realną sytuację. Harrer nie tylko postanowił skomentować wszystkie aspekty życia głównych bohaterów Contra beghardos, ale uczciwie wspomniał również o tych argumentach, których on sam nie był w stanie przekonująco podważyć. Pomimo tych obiektywnych trudności, czeski dominikanin był głęboko przekonany, że przygotowana przez niego ekspertyza dawała wszelkie podstawy do powiązania badanego ruchu świeckich z sektą begardzkich heretyków. Jednak wbrew szczerym intencjom Harrera jego Tractatus contra beghardos nie dowodził istnienia herezji w diecezji krakowskiej. Co więcej, czytelnik zamiast aktu oskarżenia przeciwko działalności grupy świeckich, otrzymał paradoksalnie potwierdzenie ich niewinności i ortodoksyjności. W świetle przeprowadzonych analiz w pełni uzasadnione jest zatem twierdzenie, że krakowscy heretycy begardzi z dzieła Harrera okazują się być pobożnymi laikami, żyjącymi we wspólnocie Kościoła. Oczywiście, ich sposób życia oraz praktyki ascetyczne wyróżniały ich spośród innych wiernych świeckich, lecz były w pełni zgodne z ustawodawstwem kościelnym. Niewątpliwie, pojawianie się tego typu inicjatyw u osób świeckich w uporządkowanym społeczeństwie średniowiecza rodziło podejrzenia ze strony władz kościelnych i świeckich. Ponadto, ta nieufność i ostrożność podsycana była z jednej strony poprzez liczne czternastowieczne kontrowersje doktrynalne i polityczne, a $\mathrm{z}$ drugiej przez samych hierarchów kościelnych, którzy zbyt często odwoływali się do strategii „dmuchania na zimne”. W tym kontekście warto pamiętać o sławnym dekrecie Ad nostrum, który potępiając begardów in generale, stał się źródłem wielu niejasności i poważnych nadużyć. Tractatus contra beghardos Henryka Harrera moglibyśmy potraktować jako jeden z interesujących przykładów i ilustracji tych nieporozumień. Jednak dzieło Harrera jest dla nas przede wszystkim oryginalnym świadectwem burzliwych dziejów formowania się wśród osób świeckich nowej pobożności. 


\section{Summary}

The Cracow's pious laymen or Beghard heretics?

From the study on the $14^{\text {th }}$ century Tractatus contra beghardos by Henryk Harrer

Tractatus contra beghardos written by a Chech Dominican Henryk Harrer is a masterpiece of exceptional value for both historians of the medieval heterodox movements as well as for scholars interested in the history of theology and law in the $14^{\text {th }}$ century. The treaty was commissioned by Cracow Dominicans in the years 1328 to 1334. Commissioning the treaty to Henryk Harrer, a stranger expert from the Prague monastery of St. Clemens was dictated by a series of controversies among Cracow clergy around the judgement of conduct of a certain group of people whose religious practices and a way of life stood out from the rest of the congregation. Undertaking the task of writing the treaty Henryk Harrer based his work around three charges pressed against the suspected of heresy: breaking off the Church and establishing an illegal organization (singularitas vite); corrupted attitude towards recognized religious practices (contemptibilitas sacramenti eucharistiae); numerous flaws and perverse disposition (pertinax voluntas). Not only did Harrer decide to comment on all aspects of life of central figures of Contra beghardos but he also honestly mentioned all arguments he was not able to undermine. Despite these objective difficulties, the Czech Dominican was certain that the expertise he came up with was sufficient to link the lay movement with the sect of Beghard Heretics.

The author of this study proved that, contrary to Harrer's keen intention, his Tractatus contra beghardos does not unambiguously show heresy in the Cracow diocese. What is more, the reader, instead of indictment against the conduct of a group of laymen paradoxically received a confirmation of their innocence and orthodoxy. In the light of analysis of the text Contra beghardos, the claim that Beghard Heretics from Harrer's work turn out to be pious layman, living in communion with the Church, seems to be fully substantiated. Of course their way of life and the practice of asceticism made them stand out from the other members of the congregation but were completely in line with the Church legislation. In this context, Harrer's work is an original testimony of numerous misunderstandings about the Beghard movement and stormy times of forming a new kind of piety among lay members of Church. 